\title{
PATHOLOGICAL PHYSIOLOGY
}

UDC 616.348-006.6-053.9615:616.89

\section{Mechanism of antisurdant action of triazin-indole derivative at experimental acoustic trauma}

\author{
V.L.Pastushenkov ${ }^{1}$, M.S.Kuznecov ${ }^{2}$, V. V.Dvorjanchikov ${ }^{2}$, \\ A. L.Pastushenkov ${ }^{3}$, M. M. Gabaeva ${ }^{4}$ \\ ${ }^{1}$ Farm-TRISAN Ltd, \\ 16, Serebristii bul., St. Petersburg, 197227, Russian Federation \\ 2 S. M. Kirov Military Medical Academy, \\ 6, ul. Academika Lebedeva, St. Petersburg, 194044, Russian Federation \\ ${ }^{3}$ North-Western State Medical University named after I. I. Mechnikov, \\ 41, Kirochnaya ul., St. Petersburg, 191015, Russian Federation \\ ${ }^{4}$ Kabardino-Balkarian State University named after H. M. Berbekov, \\ 173, ul. Chernyshevskogo, Nalchik, Kabardino-Balkarian Republic, 360004, Russian Federation
}

For citation: Pastushenkov V.L., Kuznecov M.S., Dvorjanchikov V.V., Pastushenkov A.L., Gabaeva M. M. Mechanism of antisurdant action of triazin-indole derivative at experimental acoustic trauma. Vestnik of Saint Petersburg University. Medicine, 2021, vol. 16, issue 1, pp. 13-19. https://doi.org/10.21638/spbu11.2021.102

In our research performed using model of acoustic trauma at experimental animals (female of hybrids F1 of CBA and C57BL/6 lines) influence of triazin-indole at expression level of hypoxia induced factor (HIF) in Corti's organ was studied at its therapy application. As a reference drug cytoflavin was used. Investigated drug in the form of $1 \%$ solution was introduced into animals parenterally in dosage $5,7,10 \mathrm{mg} / \mathrm{kg}$ with $2 \mathrm{hr}$ intervals after acoustic impact. Injection of cytoflavin as reference drag was performed in $1.7 \mathrm{ml} / \mathrm{kg}$ dosage. Level of HIF expression in the drug of Corti's organ was estimated using immunohistochemical method. It was found out that triazin-indole derivative increases HIF expression in Corti's cells and in neurons of spiral ganglion at acoustical traumatic impact depending on drug dosage increase. Maximal HIF expression in Corti's cells and in ganglions were noted at therapeutic dose of the drug $10 \mathrm{mg} / \mathrm{kg}$. In control group and in the group with application citoflavin in dose $1.7 \mathrm{ml} / \mathrm{kg}$ minimal HIF expression was observed. According to obtained results of performed investigation the authors concluded that antisurdant property of triazin-indole derivative is realized through the influence on HIF metabolism (probably, by blockage of prolyl hydroxylase) and enables to consider it as a target molecular during the drug application.

Keywords: hypoxia, induced fator, HIF-1, acoustical trauma, antihypoxic drugs, triasin-indole, expression, laboratory animals, mean cytochemical coefficient.

(C) St. Petersburg State University, 2021 


\section{Actuality}

According to data on 2019, among professional diseases in Russian Federation, caused by noise impact, sensorineural hearing loss is prevailed: its part in total diseases amount in the group constitutes $54.38 \%$ [1]. According to WHO data, to 2050 over 900 million persons will suffer from incapacitating loss of hearing. 1.1 billion young people (at age 12-35 years) are subjected to the risk of hearing loss as a result of noise impact. One-third of all cases hearing loss are associated with noise [2]. Acoustical traumatic organ of hearing damage by high intensity noises are noted in different industries [3;4], but most of all typical for military work $[5 ; 6]$.

One of the main pathogenetic links at acoustic trauma is internal ear microcirculation disorder [7]. It is associated in the first place with peculiarities its blood supply and anatomical organization [8]. Vascular stria edema leads to cochlear hypoxia, oxidative stress and, finally, to Corti cells death due to necrosis or apoptosis pathways activation [9].

In the modern literature great attention is paid to hypoxia-induced factor (HIF), for discovery and study of which Gregg L. Semenza, Peter J. Ratcliff and William Bill George Kaelin awarded Nobel Prize in physiology and medicine in 2019 [10; 11]. HIF molecule presents itself a heterodimer, consisting of oxygen-depending transcriptionally active subunits HIF- $1 \alpha$ and HIF- $2 \alpha$ and oxygen-independent subunit HIF-1 $\beta$ [10]. There also exists isoform HIF-3 $\alpha$, capable to inhibit HIF-1/2 $\alpha$ action [12]. In normal oxygen conditions HIF-1 $a$ molecule hydroxylates with prolyl hydroxylase (PHD) ferment participation, interacts with protein Von Hippel-Lindau (pVHL), being ubiquitinylated and subjected to proteasomal degradation [13]. Molecular oxygen take part in reaction of hydroxylation, as well as ions of iron and ascorbic acid and in case of insufficiency of one of the components this reaction becomes impossible, leading to increase of HIF-1a number [14]. In case of oxygen insufficiency, two subunits HIF- $1 \alpha$ and HIF- $1 \beta$ penetrate into cell nucleus and regulate expression of hundreds target genes, participated in angiogenesis, erythrogenesis, carbohydrate metabolism, cellular proliferation and etc. $[15 ; 16]$.

J.H.Pak in his work showed, that in conditions of preconditioning using cobaltous chloride, elevated HIF-1 1 expression take place and protecting action of Corti's organ is implemented in case of noise impact [17].

Actual is a search of medicines and healthcare products, directed on struggle with hypoxic hearing organ damage in case of acoustical traumatic impact, including impact on HIF molecule.

\section{Purpose}

To study the level of hypoxia-induced factor HIF-1a in Cortia's cells using the model of acoustic trauma at application triasin-indole derivative.

\section{Experimental animals and methods}

Experiments were carried out on 65 mice, females of F1 hybrids CBA and C57BL/6 lines with weight at least $17 \mathrm{~g}$ and 4-12 weeks age, delivered from mous bank of Russian Medical science Academy "Rappolovo" (Leningrad region, Russia). Experiments were carried out after 14 day of animals adaptation in vivarium. All the researches were 
performed in accordance with requirements of European Convention for the Protection of Vertebrate Animals used for Experimental and Other Scientific Purposes (Strasbourg, 1996), good laboratory practice (Order of Ministry of Labor and Social Protection, Russian Federation, dated 23.08.2010), guidelines on preclinical studies. Mice euthanasia was performed by means of ethal dose of anesthesia, used in experiments - intra-abdominal injections of Telazol (50-70 mg/kg).

New derivative of triazin-indole (Trisan) 3-[(2-morfolinoetiltio] $-5 \mathrm{H}-1,2,4$ triazino [5,6-b] indole hydrochloride, monohydrate, for the first time synthesized by doctor of science, professor L. V. Pastushenkov at pharmacological department of Military Medical Academy named after S.M. Kirov. As a reference drug citoflavin was used, that provide antioxidative, antihypoxic action which is used in ENT practice for treating acute and chronic bradyacusia [18].

At modeling acute acoustical trauma after initial registration auditory evoked potentials, animals during 3-hour white noise impact at level $107 \mathrm{~dB}$ in ultrasonic range and bandwidth from 3 to $100000 \mathrm{~Hz}$ (noise generator GRC Concord 1390-B, USA). Noise level $107 \mathrm{~dB}$ corresponded to the level, measured by Brüel \& Kjr system (Denmark): $6.5 \mathrm{~mm}$ gauge microphone of 4135 type, preamplifier 2633 and measuring amplifier 2606 in the point of tympanic membrane location of investigated ear. Auditory evoked potential registration was performed directly after acoustic impair impact, and also after 1 and 2 hours after acoustic trauma.

$1 \%$ solution of investigated drug Trisan was injected into animals intravenously, intramuscularly and abdominally using single-use syringes. For convenience of injecting resulting $1 \%$ Trisan solution was diluted using physiological solution $\mathrm{NaCl}(1 \mathrm{ml} 1 \%$ Trisan solution and $9 \mathrm{ml} 0.9 \% \mathrm{NaCl}$ solution). With therapeutic purpose, the drug was injected in $5,7,10 \mathrm{mg} / \mathrm{kg}$ dosage in 2 hours after acoustic impact. In the same manner dilution and injection of reference drug, citoflavine, was performed in $1.7 \mathrm{ml} / \mathrm{kg}$ dosage. In control group experimental animals physiological solution was injected.

After the experiment, Corti's organ was extracted as a part of excised temporal bone and then was fixed using $10 \%$ normal $(\mathrm{pH} \mathrm{7,4)}$ formaldehyde solution for 12 hours. Obtained fixed samples were subjected to decalcination by means of incubation in solution for rapid decalcination (Bio-Vitrum, Russia) for 30 minutes. Histological specimens processing and imbibition samples by paraffin was performed using automated tissue processor Exelsior ES (Thermo, Great Britain). Paraffin section 5 micrometers thick were obtained by means of semi-automated rotary microtome with system of slice transfer HM350 (Thermo, Great Britain).

Immunohistochemical investigations were carried out with application peroxidaselabeled rabbit monoclonal primary antibodies (Immunotech, Russia). Estimate of coloring was carried out by mean cytochemical coefficient (MCC), developed by the authors. Numbers from 1 to 6 were used to denote intensity of coloring at HIF-1a expression.

\section{Results}

While analyzing obtained materials it was noted: absence of HIF-1 expression by neuroreceptor system cells; low HIF expression by cells in spiral ganglion in case of control group and in the group where citoflavine was used (Fig. 1). 
At therapeutic dose $5 \mathrm{mg} / \mathrm{kg}$ of the drug low HIF-1 expression by neuroreceptor system cells, moderate HIF-1 expression by spiral ganglion cells. In case of drug injection at $7 \mathrm{mg} / \mathrm{kg}$ dose moderate HIF-1 expression by neuroreceptor system cells and by spiral ganglion cells as well. Noticeable HIF-1 expression was observed in case of application Trisan dose $10 \mathrm{mg} / \mathrm{mg}$, injected in 2 hours after acoustic traumatic impact (Fig. 2).

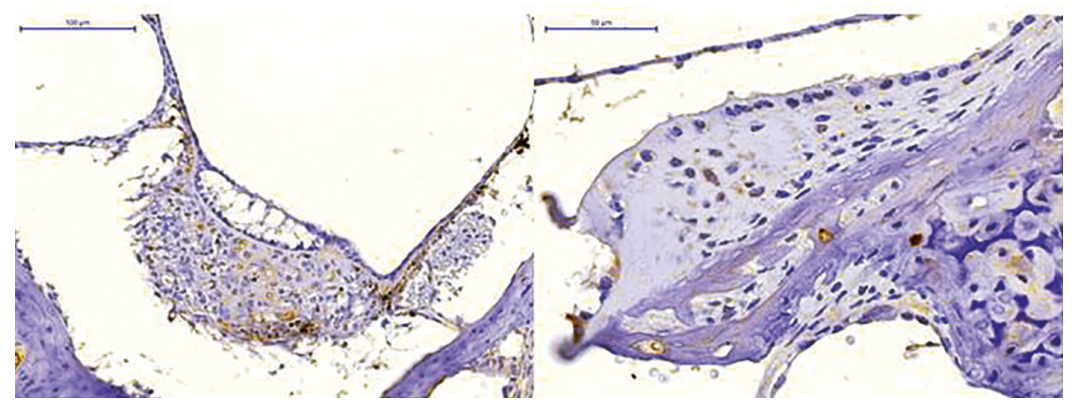

Fig. 1. Absence of HIF-1 expression by neuroreceptor system cells; low HIF expression by spiral ganglion cells (control group - to the left; citoflavine - to the right)

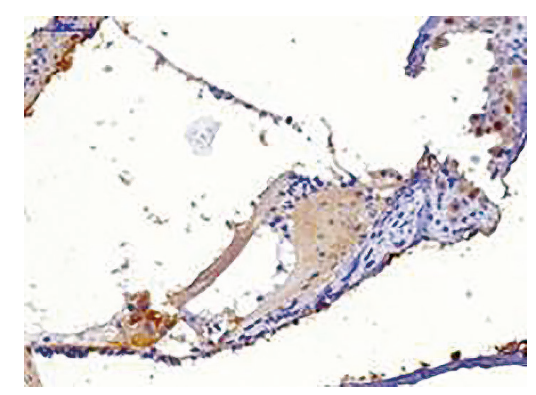

Fig. 2. HIF-1 expression by neuroreceptor system cells and by spiral ganglion cells (therapeutic dose $10 \mathrm{mg} / \mathrm{kg}$ )

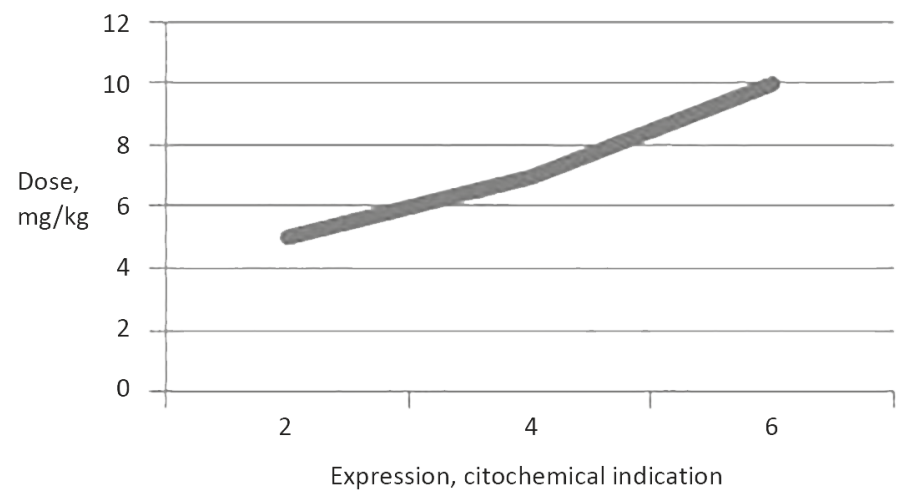

Fig. 3. Level of HIF-1 expression dependence (using mean citochemical indication) (abscissa axis) on injected therapeutic dosage of triasin-indole (ordinate axis) 
With the help of obtained results it was found out that increase of HIF-1 expression in Corti's cells and in neurons of spiral ganglion at application of triasin-indole derivative depends on the dose used and coincide with electrophysiological changes in experimental animals (Fig. 3).

This regularity enables to suppose, that molecule target for the drug is HIF. Maximal HIF expression in Corti's cells and in ganglions were noted at therapeutic dose of the drug $10 \mathrm{mg} / \mathrm{kg}$.

\section{Discussion}

Increase of HIF expression level at application of medicinal drugs according to literature data are due to ferment PHD suppression, which participated in HIF molecule hydroxylation, that lead to its proteoclastical degradation [19-22]. Deferoxamine and dimethyloxalylglycine inactivate PHD, forming complex with iron, which is its cofactor [23; 24]. Cobaltous chloride increases accumulation and transcriptional activity of HIF due to iron and ascorbic acid exclusion from its metabolism [26].

In the recent works it was shown that HIF stability is reached due to application micro-RNA and VP16-HIF-1 $\alpha$ viruses by means of modern genetic engineering methods $[27 ; 28]$.

According to the data, obtained in course of our work performance, triasin-indole derivative possesses antisurdant property due to the influence on HIF expression level. Most probably, due to ferments blockage participated in its degradation (prolyl hydroxylase). It enables to consider that complex as perspective pathogenetic drug for prevention and treating bradyacusia of noise etiology.

\section{Conclusions}

Based on the results of our investigation and literature analysis, we concluded that triasin-indole derivative possesses possesses antisurdant property due to the influence on HIF expression level as molecule target for the drug. With increase of triasan dose regular increase of HIF-1 expression in Corti's cells and in ganglions were noted, that coincided with elctrophysiological changes in experimental animals. We suppose that mechanism of the drug action is associated with ferments blockage which participated in its proteosomal degradation (prolyl hydroxylase).

\section{References}

1. On the State of Sanitary and Epidemiological Welfare of the Population in the Russian Federation In 2019: State Report. Federal Service for Surveillance on Consumer Rights Protection and Human Wellbeing, 2020, p. 134. (In Russian)

2. Deafness and hearing loss. Available at: https://www.who.int/ru/news-room/fact-sheets/detail/deafness-and-hearing-loss (accessed: 20.03.2019).

3. Adeninskaia E. E., Gorblianskii Iu. Iu., Khoruzhaia O. G. Comparative analysis of features professional employees sensorineural hearing loss in a variety of sectors. Acta Biomedica Scientifica, 2013, no. 6, pp. 87-91. (In Russian)

4. Ntlhakana L., Nelson G., Khoza-Shangase K. Estimating miners at risk for occupational noise-induced hearing loss: A review of data from a South African platinum mine. S. Afr. J. Commun. Disord., 2020, vol. 67 , no. 2 , pp. $1-8$. 
5. Yankaskas K., Hammill T., Packer M., Zuo J. Editorial: Auditory injury - A military perspective. Hear. Res., 2017, no. 349, pp. 1-3.

6. Muhr P., Johnson A. C., Selander J., Svensson E., Rosenhall U. Noise Exposure and Hearing Impairment in Air Force Pilots. Aerosp. Med. Hum. Perform., 2019, vol. 90, no. 9, pp. 757-763.

7. Petrova N.N. Modern look on ethiological and pathogenetical therapy of sensorineural hearing loss. Obzory po klinicheskoi farmakologii i lekarstvennoi terapii, 2010, no. 2, pp. 35-40. (In Russian)

8. Burak G. G., Samsonova I.V., Kobets Iu. G. Variants of divergence, topography and branching of labyrinthine arteries: clinical and anatomical aspects. Vestnik VGMU, 2009, vol. 8, no. 2, pp. 1-23. (In Russian)

9. Kurabi A., Keithley E. M., Housley G. D., Ryan A. F., Wong A. C. Cellular mechanisms of noise-induced hearing loss. Hear. Res., 2017, no. 349, pp. 129-137.

10. Semenza G. L., Wang G.L. A nuclear factor induced by hypoxia via de novo protein synthesis binds to the human erythropoietingene enhancer at a site required for transcriptional activation. Mol. Cell. Biol., 1992, vol. 12, no. 12, pp. 5447-5454.

11. Semenza G. L. Pharmacologic Targeting of Hypoxia-Inducible Factors. Annu Rev. Pharmacol. Toxicol., 2019, no. 59, pp. 379-403.

12. Duan C. Hypoxia-inducible factor 3 biology: complexities and emerging themes. Am. J. Physiol. Cell. Physiol., 2016, vol. 310, no. 4, pp. 260-269.

13. Zhang J., Zhang Q. VHL and Hypoxia Signaling: Beyond HIF in Cancer. Biomedicines, 2018, vol. 6, no. 1, p. 35 .

14. Lanigan S.M., O'Connor J. J. Prolyl hydroxylase domain inhibitors: can multiple mechanisms be an opportunity for ischemic stroke? Neuropharmacology, 2019, no. 148, pp. 117-130.

15. Nagao A., Kobayashi M., Koyasu S., Chow C.C.T, Harada H. HIF-1-Dependent Reprogramming of Glucose Metabolic Pathway of Cancer Cells and Its Therapeutic Significance. Int. J. Mol. Sci., 2019, vol. 20 , no. 2, p. 238.

16. Karagiota A., Kourti M., Simos G., Mylonis I. HIF-1a-derived cell-penetrating peptides inhibit ERKdependent activation of HIF-1 and trigger apoptosis of cancer cells under hypoxia. Cell. Mol. Life Sci., 2019, vol. 76, no. 4, pp. 809-825.

17. Pak J.H., Yi J., Ryu S., Kim I. K., Kim J.W., Baek H., Chung J.W. Induction of Redox-Active Gene Expression by $\mathrm{CoCl} 2$ Ameliorates Oxidative Stress-Mediated Injury of Murine Auditory Cells. Antioxidants (Basel), 2019, vol. 8, no. 9, p. 399.

18. Zhuravskii S. G. Improvement of speech discrimination with cytoflavin in patients with chronic sensorineural deafness. Vestn. Otorinolaringol., 2010, no. 4, pp. 82-86. (In Russian)

19. Maxwell P.H., Eckardt K. U. HIF prolyl hydroxylase inhibitors for the treatment of renal anaemia and beyond. Nat. Rev. Nephrol., 2016, vol. 12, no. 3, pp. 157-168.

20. HoWangYin K. Y., Loinard C., Bakker W., Guérin C. L., Vilar J., d’Audigier C., Mauge L., Bruneval P., Emmerich J., Lévy B. I., Pouysségur J., Smadja D. M., Silvestre J. S. HIF-prolyl hydroxylase 2 inhibition enhances the efficiency of mesenchymal stem cell-based therapies for the treatment of critical limb ischemia. Stem. Cells, 2014, vol. 32, no. 1, pp. 231-243.

21. Strowitzki M. J., Cummins E. P., Taylor C. T. Protein Hydroxylation by Hypoxia-Inducible Factor (HIF) Hydroxylases: Unique or Ubiquitous? Cells, 2019, vol. 8, no. 5, p. 384.

22. Nagle D. G., Zhou Y.D. Natural product-derived small molecule activators of hypoxia-inducible factor-1 (HIF-1). Curr. Pharm. Des., 2006, vol. 12, no. 21, pp. 2673-2688.

23. Wang K., Jing Y., Xu C., Zhao J., Gong Q., Chen S. HIF-1 1 and VEGF Are Involved in DeferoxamineAmeliorated Traumatic Brain Injury. J. Surg. Res., 2020, no. 246, pp. 419-426.

24. Wang W. S., Liang H. Y., Cai Y. J., Yang H. DMOG ameliorates IFN- $\gamma$-induced intestinal barrier dysfunction by suppressing PHD2-dependent HIF-1a degradation. J.Interferon Cytokine Res., 2014, vol. 34 , no. 1, pp. 60-69.

25. Shafighi M., Olariu R., Fathi A.R., Djafarzadeh S., Jakob S. M., Banic A., Constantinescu M. A. Dimethyloxalylglycine stabilizes HIF- $1 \alpha$ in cultured human endothelial cells and increases random-pattern skin flap survival in vivo. Plast. Reconstr. Surg., 2011, vol. 128, no. 2, pp. 415-422.

26. Mikami H., Saito Y., Okamoto N., Kakihana A., Kuga T., Nakayama Y. Requirement of Hsp105 in CoCl2-induced HIF-1a accumulation and transcriptional activation. Exp. Cell. Res., 2017, vol. 352, no. 2, pp. 225-233.

27. Serocki M., Bartoszewska S., Janaszak-Jasiecka A., Ochocka R.J., Collawn J.F., Bartoszewski R. miRNAs regulate the HIF switch during hypoxia: a novel therapeutic target. Angiogenesis, 2018, vol. 21, no. 2, pp. 183-202. 
28. David B. T., Curtin J. J., Goldberg D. C., Scorpio K., Kandaswamy V., Hill C. E. Hypoxia-Inducible Factor $1 \alpha$ (HIF-1 $\alpha$ ) Counteracts the Acute Death of Cells Transplanted into the Injured Spinal Cord. eNeuro, 2020, vol. 7, no. 3, pp. 1-17.

Received: January 21, 2021

Accepted: March 25, 2021

Authors'information:

Vladimir L.Pastushenkov — Grand PhD in Medicine, Professor; pastprof@mail.ru Maxim S.Kuznecov - PhD in Medicine; mskuznecov2@mail.ru

Vladimir V.Dvorjanchikov — Grand PhD in Medicine, Professor; vmedalor@mail.ru Alexander L.Pastushenkov — PhD in Medicine, Associate Professor; palunov@mail.ru Madina M. Gabaeva - PhD in Medicine, Associate Professor; madishka0806@mail.ru 